\title{
Ethnobotanical Investigation of Some Medicinal Plants used by Tribes of Mandla District, Madhya Pradesh, India
}

\author{
Kumud Sandya ${ }^{1}$, Ganesh Singh Sandya ${ }^{2}$ \\ ${ }^{1}$ Department of Botany, Govt. Girls P.G. College, Shahdol - 484001 (India) \\ ${ }^{2}$ Department of Botany, Pt. S. N. S. Govt. P. G. College Shahdol - 484001 (India)
}

\begin{abstract}
Present paper deals with 30 ethnobotanical plants have been identified for the treatment of various disease. Harbarium has been prepared which contains information pertaining to botanical name, local name, plants used, their dose and process of administration. A survey of ethnobotanical plants of Mandladistrict has been carried out with co-operation of Tribal villagers.
\end{abstract}

Keywords: Ethnobotanical plants,Tribes, Mandla, Madhya Pradesh.

\section{Introduction}

Mandla district is a Baiga and Gond tribes dominated district. Mandla district situated at 22035 ' 00 " N. Latitude and 800 21'00' E. Longitude. This District in the located hilly and forest areas of Maikal hill range of the Satpuras, in mostly scattered habitation. The District situated in the east- Central part of Madhya Pradesh lies almost entirely in the catchment of river Narmada and it tributaries. A District with a glorious history, Mandla comprises of numerous rivers and endowed with rich forests . "Khanha National Park " Located in this District, its world's famous Tiger Sancturary .One of the hottest targets for both the domestic as well as Foreign tourist. The extreme length of this District is about $133 \mathrm{Kms}$. from north to south and extreme breath is $182 \mathrm{Kms}$ from east to west. It is covered a total area of $8771 \mathrm{Sq} . \mathrm{km}$.and consists a total population of 10,53,522. There are 9 Block , 6 Tehsils and 1221 habitable village in the District. This District is total Tribals population 5,11,798 and total geographical area $8771 \mathrm{Kms}$ scattered habitation in villages.

The rainfall various considerably from year. The Survey of folk Medicinal Plants was conducted for one consecutive years in villages of 6 Blocks in Mandla District. Ethnomedicinal information collected from the native information. Oral interviews were held villages and information recorded at the spot and Ethnomedicinal Plants was collected and preserved for future users and marked by vouchers numbers. The Plants species were identified with the help of available floras. Some doubtful Folk Medicinal Plants are confirmed at the herbaria of Forest Research Institute (F.R.I)Jabalpur (M.P) India and Botanical Survey of India (B.S.I)Central Circle Allahabad (U.P.) India.
MandlaDistrict is floristically very rich and harbours a wide range of biodiversity.People living in these forests and adjacent rural areas depend upon plants for their daily needs and food. Baiga tribal villagers have good knowledge about medicinal plants and their uses in different types of diseases. A perusal of literature shows that no systematic study and survey from ethnobotanical and ethnobotanical point of view has been carried out in the present area of investigation. The present communication deals with 30 ethnobotanical plant used by the tribal communities in habiting the region of Mandla district forvarious disease treatment by the Tribes. The plants are arranged alphabetically each by botanical name, family, local name and use of plants. Plants were collected during flowering period with the help of tribals andvaidys. Parts of ethnobotanical plants used in the treatments of many types disease and other information's were recorded as stated by the tribals and vaidyas. The specimens were identified with the help of published floraand relevant authorities.Some other workers who have contributed in the field of ethnobotany as Jain(1981,1963,1965 and 1991), Agrawal (1997), Ahirwar (2010, 2011, 2014 and 2015),Khan et al (2008), Biswas and Mukerjee (2003), Busia (2005), Chopra (1956), Hemadri and Rao (1989), Kumar (2007), Maheswari (1964), Masihet al (2013) Miller (1990) and Oommanchan and Masih (1989).

\section{Results and Discussion}

During present paper we have identified 30 Ethnobotanical plants, which are uses by tribes of Mandla district in their daily life for the treatment of various diseases. Most of these plants are wild and some plants are cultivated. The ethnobotanical plants have been listed alphabetically(Table 1).

\section{Material and Methods}




\section{International Journal of Science and Research (IJSR) \\ ISSN (Online): 2319-7064}

Index Copernicus Value (2013): 6.14 | Impact Factor (2014): 5.611

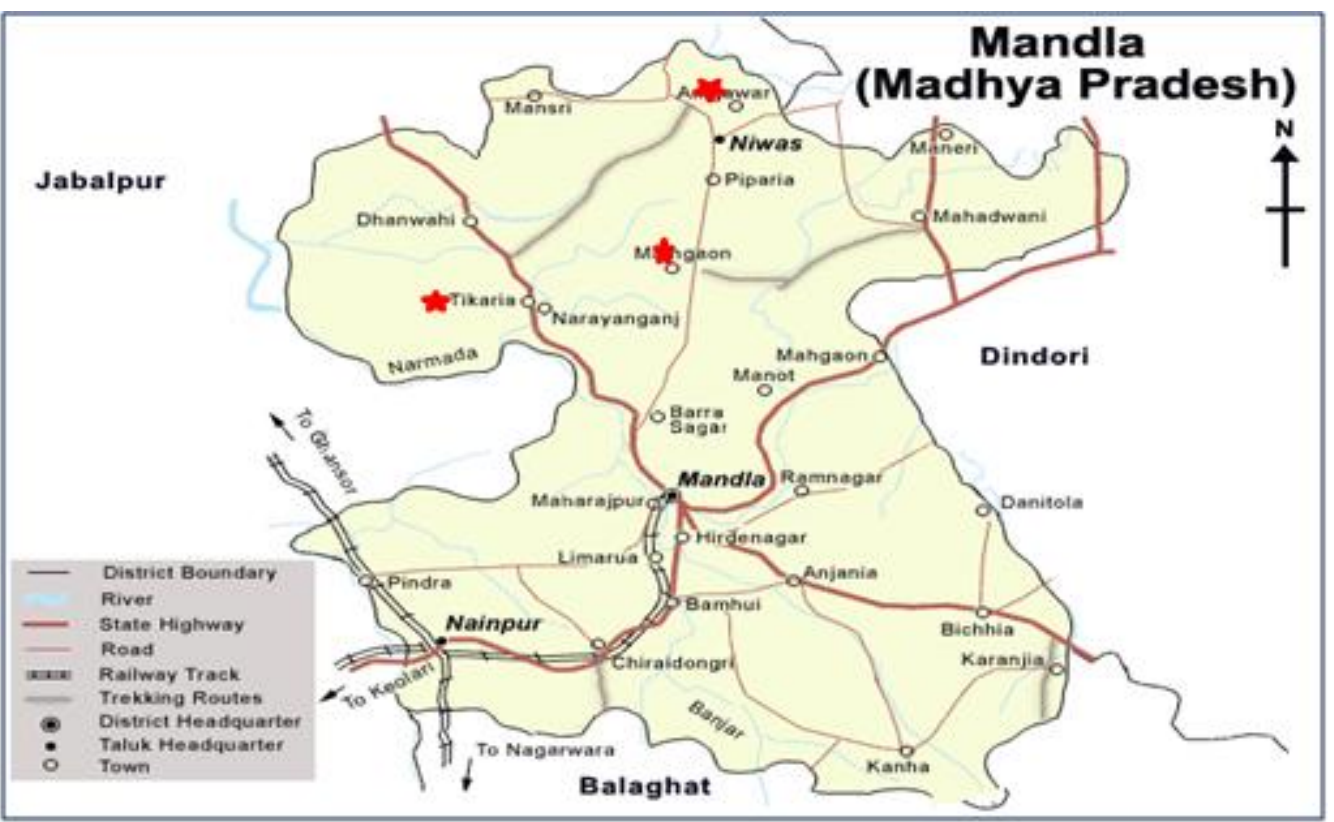

Figure 1: Location Map of Madhya Pradesh in Mandla District.

Table 1: Shows Ethnobotanical plants uses of Tribes in Mandla District, Madhya Pradesh, India

\begin{tabular}{|c|c|c|c|c|}
\hline S.No. & Name of Family & Botanical Name & Local Name & Ethnobotanical Used \\
\hline $\mathbf{1}$ & Apiaceae & Centellaasiatica(L). Urban & Bramhi & $\begin{array}{l}\text { Entire plant used as nervine tonic, and skin diseases as weak } \\
\text { sedative, cardio depressant, hypotensive and in leprosy. }\end{array}$ \\
\hline 2 & Asteraceae & EcliptaprostrataL. & \begin{tabular}{c|c} 
Kala \\
Bhegraj
\end{tabular} & $\begin{array}{l}\text { Entire plant tonic given in spleen enlargement and leaf juice given } \\
\text { in eczema and as hair tonic. }\end{array}$ \\
\hline 3 & Apocynaceae & $\begin{array}{l}\text { Rauvolfia serpentine (L.) } \\
\text { Benth. }\end{array}$ & Sarapgandha & $\begin{array}{l}\text { Leaf juice is used as remedy for opacity of cornea. Root is sedative, } \\
\text { reduces hypertension. }\end{array}$ \\
\hline 4 & Asclepiadaceae & Calotropisprocera $\mathrm{Br}$. & Madar & $\begin{array}{l}\text { Flowers are used in cold, cough and Asthma Powdered Root bark } \\
\text { used in dysentery. Fresh leaves in ulcer and as wormicidal. }\end{array}$ \\
\hline 5 & Acantahceae & AdhatodaVasicaNees & Adusa & Leaf decoction is used in cough bronchitis and rheumatism. \\
\hline 6 & Acantahceae & Hygrophilaauticulata(Schum) & Talmakhana & $\begin{array}{c}\text { Leaves, seeds and roots are used as diuretics and also for jaundice, } \\
\text { dropsy, rheumatism and urinogenital disorder }\end{array}$ \\
\hline 7 & Amaranthaceae & AchyranthesasperaL. & Chirchitta & $\begin{array}{c}\text { Used in cough and its decoction is given in renal dropsy and } \\
\text { bronchial infection treatment of phyrrhoeafever,enlargement of liver } \\
\text { and spleen. }\end{array}$ \\
\hline 8 & Bombacaceae & Bombaxceiba $\mathrm{L}$ & Semur & Root is stimulant, tonic and chiefly given in impotency. \\
\hline 9 & Combretaceae & $\begin{array}{l}\text { Terminalia arjuna(Roxb.) } \\
\text { Wt. \& Am. }\end{array}$ & Arjun & $\begin{array}{l}\text { Bark infusion used in heart troubles and leaf juice in earache, } \\
\text { hypertension and as diuretic and has tonic effect in cirrhosis of } \\
\text { lever. }\end{array}$ \\
\hline 10 & Cucurbitaceae & Cocciniagrandis $(\mathrm{L})$. Voigt & Kundru & Juice from leaves and roots is used in diabetes. \\
\hline 11 & Cactaceae & Opundtiaelatior. Mil. & Nagphani & $\begin{array}{l}\text { Baked fruit is given in whooping cough and a syrup of the fruit } \\
\text { increases secretion of bile. }\end{array}$ \\
\hline 12 & Caesalpiniaceae & Cassia fistula $\mathrm{L}$. & Amaltash & $\begin{array}{l}\text { Root with black pepper and leaves of kathal applied to cattle for } \\
\text { giving relief to swollen throat. }\end{array}$ \\
\hline 13 & Caesalpiniaceae & Cassia tora $\mathrm{L}$. & Chakwda & Leaf and seeds used in skin disease for ring worm and itch. \\
\hline 14 & Convolvulaceae & CuscutareflexaRoxb. & Amarbel & Seeds used in ulcer and liver disorders. \\
\hline 15 & Dipterocarpaceae & Shorearobusta Gaertn f. & Sal & Resin is used in skin diseases, diarrhea anddysentery. \\
\hline 16 & Fabaceae & $\begin{array}{l}\text { Butea monosperma(Lamk) } \\
\text { Tamb }\end{array}$ & Palas & $\begin{array}{l}\text { Seeds are internally administerd as an anthelmintic in treatment of } \\
\text { round worms. Gum is used in treatment of diarrhoea. }\end{array}$ \\
\hline 17 & Fabaceae & DalbergiasissooRoxb & Shisham & Decoction of leaf Useful in gonorrhoea. \\
\hline 18 & Fabaceae & Mucunapruriens(L) DC & Kemmach & $\begin{array}{l}\text { Root used in paralysis seeds are used as nervine tonic, menses } \\
\text { troubles and as vermifuge, strong infusion of roots mixed with } \\
\text { honey is given in cholera. }\end{array}$ \\
\hline 19 & Lythraceae & LawsoniainerdmisL. & Mehndi & $\begin{array}{l}\text { Lea paste or decoction used as gargle in sore throat, burns, bruises } \\
\text { and skin inflammation, Seeds useful in urinary troubles. }\end{array}$ \\
\hline 20 & Lamiaceae & $\begin{array}{l}\text { Leucascephalotes(Wild.) } \\
\text { (Roth) Spr. }\end{array}$ & Gumi & $\begin{array}{l}\text { Leaf used as digestive antiseptic and earache and fever. Flowers are } \\
\text { used in cough and cold. }\end{array}$ \\
\hline 21 & Lamiaceae & Ocimumamericanum L. & Kali tulsi & Leaf decoction is given in Maleria and abdominal diseases. \\
\hline 22 & Menispermaceae & Tinosporacordifolia(L.)Merr & Gurch & $\begin{array}{l}\text { Root extract is fever, cold cough, as blood purifier, in acidity and } \\
\text { jaundice. }\end{array}$ \\
\hline 23 & Meliaceae & Azadirachtaindica A. Juss & Neem & $\begin{array}{c}\text { Bark, leaf and fruit decoction is antiseptic and used in ulcer, eczema } \\
\text { and skin diseases. }\end{array}$ \\
\hline
\end{tabular}

\section{Volume 4 Issue 12, December 2015}

www.ijsr.net 
International Journal of Science and Research (IJSR)

ISSN (Online): 2319-7064

Index Copernicus Value (2013): 6.14 | Impact Factor (2014): 5.611

\begin{tabular}{|c|c|c|c|c|}
\hline $\mathbf{2 4}$ & Mimosaceae & Acacia nilotica (L.) Del. & Babul & Bark used in diarrhea, dysentery and diabetes. \\
\hline $\mathbf{2 5}$ & Mimosaceae & Albizdialebbeck(L.)Willd & Siris & Bark and seeds given in piles and diarrhea. \\
\hline $\mathbf{2 6}$ & Nyctaginaceae & Boerhaaviadiffusa L. & Punarnava & Root is laxative and used in asthma, jaundice and dropsy. \\
\hline $\mathbf{2 7}$ & Papaveraceae & Argemonemexicana $\mathrm{L}$ & Pilikateli & Stem latex used in dropsy, jaundice and conjunctivitis. \\
\hline $\mathbf{2 8}$ & Papaveraceae & Papaver somniferumL & Afeem & $\begin{array}{c}\text { Flower, fruits and Seeds have pain releasing and sleeping effects } \\
\text { and useful in irritating cough, pneumonia, ulcers, gastritis and } \\
\text { influenza }\end{array}$ \\
\hline $\mathbf{2 9}$ & Rutaceae & Aegle marmelos $(\mathrm{L})$ Corr & Bel & $\begin{array}{c}\text { Fruits is given in diarrhea dysentery irriation of alimentary canal, } \\
\text { fever and as tonic and cooling agent. }\end{array}$ \\
\hline $\mathbf{3 0}$ & Sapotaceae & $\begin{array}{c}\text { Madhucalongifolia } \text { Koen) } \\
\text { Mac Br. }\end{array}$ & Mahua & $\begin{array}{c}\text { Decoction of bark is used in incurring bleeding gums and ulcers. } \\
\text { Flowers are used in cough and bronchitis. }\end{array}$ \\
\hline
\end{tabular}

\section{Acknowledgements}

The authors are thankful to their respective college authorities for granting permission to carry out of this work.

\section{References}

[1] Agrawal, D.P. (1997) Traditional Knowledge Systems and Western Science current science73, 731-733.

[2] Ahirwar,R.K.(2010) A Survey of Medicinal Plants used by tribals of Anuppur District, central India.Ind. J. Applied \&Pure Bio. Vol.25 (II) 227-230.

[3] Ahirwar,R.K. (2011) Ethnomedicinal Plants Studies in Jaitpur Forest range of Shahdol, District, Central India. Ad. PlantSci. Vol.24 (II) 681-684.

[4] Ahirwar,R.K. (2014) Utilization of Medicinal Plants by the Tribes of Bhatiya, District Shahdol, Madhya Pradesh. Int.J.Sci.andRes.3(9).149-151.

[5] Ahirwar, R.K.(2010) Ethnomedicinal uses of plant roots from Shahdol district of M.P. India. Ind. J.Appl. Pure Bio. 25 (1) 71-76.

[6] Ahirwar, R.K. and Singh,G.K. (2011) Some anti diabetic plants from Dindori District of Madhya Pradesh (India). Ind. J.Appl. pure Bio.26 (2) 269-271.

[7] Ahirwar, R.K. (2015) Diversity of Ethnomedicinal Plants in Boridand Forest of District Korea, Chhattisgarh,India. American Journal of Plant Sciences, 6, 413-425. http://dx.doi.org/10.4236/ajps.2015.62047

[8] Biswas, T.K. and Mukherjee, B. (2003) Plant Medicines of Indian Origin for Wound Healing Activity: A Review. In- ternational Journal of Lower Extremity Wounds, 2, 25-39.

[9] Busia, K. (2005) Medical Provision in Africa-Past and Present. Phytotherapy Research, 19, 919-923. http://dx.doi.org/10.1002/ptr.1775

[10] Chopra R.N, Nyar SL \& Chopra I.C.(1956) Glossary of Indian Medicinal Plants ,Council of scientific and Industrial Research, New Delhi.

[11] Hemadri, Koppala\&Rao.S.S.(1989) Folk Medicine of Bastar,J.Ethnobotany1, 61-66.

[12] Jain S.K. (1963) Observation on the Tribals of Madhya Pradesh Vanyajati.11, 177-183.

[13] Jain, S.K. (1991) Dictionary of folk Medicines and Ethnobotany, Deep Publications, New Delhi.

[14] Jain, S.K . (1981) Glimpses of Ethnobotany, Oxford \& IBH. NewDelhi.

[15] Jain, S.K.(1965) Medicinal Plant lore of tribals of Bastar Econ.Bot, 19, 236-250.
[16] Khan.A.A, Agnihotri, S.K, Singh M.K \& Ahirwar, R.K. (2008) Enumaration of certain Angiospermic plants used by Baiga tribe for Conservations of Plants Species. Plant Archives8, (I) 289-291.

[17]Kumar, K. (2007) Working Plan of North Surguja, Ambikapur Forest Department Govt.of Chhattisgarh, Raipur.

[18] Khan.A.A, Agnihotri, S.K, Singh M.K \& Ahirwar, R.K. (2008) Observation of Certain Plants used in skin diseases by Baiga Tribes of Mandala district. Plant Archives 8. (I) 283-284.

[19] Maheswari, J.K. (1964) A Contribution to the Flora Kanha National Park, Madhya Pradesh Bull. Bot. surv.India. 5(2), 177-140.

[20] Masih, V., Sahu, P.K. and Singh, M. (2013) Observation on Ethno-Medicinal Herbs of Dantewada, Chhattisgarh India. Interna- tional Journal of Drug Discovery and Herbal Research,3, 644-648.

[21] Miller, N.N., (1990) Traditional medicine in East Africa, America Universities field staff report, 22, pp $1-15$.

[22] Oommachan M, Masih S.K. (1989) Ethnobotanical observations on certain forest plants of Jabalpur (M.P.) Ind. J. Appl. pure Bio.4 (2) 73-78 